\title{
An Overview of Hospital Informartion System at Dental Hospital (RSGM) UMY Based on The Perspective of Dental Students
}

\author{
Puji Lestari *, Titih Huriyah ${ }^{* *}$, Fitri Arofiati ${ }^{* * *}$ \\ ${ }^{*}$ University of Muhammadiyah Yogyakarta, Indonesia \\ *** Universitas Muhammadiyah Yogyakarta, Indonesia \\ ****Universitas Muhammadiyah Yogyakarta, Indonesia \\ DOI: 10.29322/IJSRP.11.10.2021.p11866 \\ http://dx.doi.org/10.29322/IJSRP.11.10.2021.p11866
}

\begin{abstract}
The Hospital Information System (HIS) is a collection of several parts of the way that relate to one another and form a unified whole that is in a hospital. The ongoing Hospital Information System at RSGM UMY is needed in its work activities. Therefore, it is necessary to have a quality measurement of the RSGM information system. This research uses a quantitative research method. The study population was dental students who used HIS at RSGM UMY, which in this study the subjects were about 200 people. Data collected using questionnaires and analyzed using descriptive analysis with percentage analysis techniques. From the results concluded that the HIS users at RSGM UMY stated that they were quite satisfied. This can be seen from the average results of the respondents where the contents of the information generated by the HIS software were needed by the users, producing the right reports with the accuracy of HIS, besides that HIS was able to provide information according to what is needed.
\end{abstract}

Keyword- Hospital Information System, RSGM UMY, Dental Students

\section{INTRODUCTION}

$\mathrm{H}$ ospital Information System (HIS) is a collection of several parts and information that relate to one another and form a complete unit in a hospital, to analyze data sequentially from the beginning (input), then be analyzed, to make out the results (output) in the form of information to make a decision and achieve a desired goal [1].

Based on the use of this system, the ongoing development of the HIS at RSGM UMY is needed. Users are expected to be willing and able to implement the information system in their work activities. If the user does not want to accept or use the existing HIS, then the use of the HIS will not give a meaningful change. Therefore, it is necessary to have a quality measurement of the RSGM information system. The RSGM information system is used by several types of users in carrying out their activities, especially for dental students. in her research on user's perceptions of hospital management information system medical record section with the Pieces method in the Hospital PKU Muhammadiyah Yogyakarta Unit II Hospital, shows that there are weaknesses in the system of the performance, information, economics, control, efficiency and service aspects.

Another study by Hafis Nur Wicaksono [2] in research on the analysis of the HIS success using the updated D \& M is success model approach in the Kaliwates General Hospital, Jember, in his research it shows that there is an influence on the quality of information with the intention to use it. There is an effect of information quality on user satisfaction. There is an effect of system quality with the intention to use, there is an effect of system quality on satisfaction.

There is an effect of service quality with the intention to use. There is an effect of service quality with satisfaction. There is an effect of the intention to use with usage. There is an effect of usage with user satisfaction. There is an effect of user satisfaction with the intention to use. There is an effect of usage with net benefits. There is an effect of net benefits with intensity of use. There is an effect of net benefits with user satisfaction and there is an effect of user satisfaction with net benefits.

\section{RESEARCH METHOD}

This research uses quantitative research. Researchers are more concerned with the broad aspect of the data so that the data or research results are considered to be a representation of the entire population [3]. The population of this study for data included dental students who used HIS at RSGM UMY. Questionnaires distributed through Google forms, the respondents in this study were 200 peoples.

\section{WRITE DOWN YOUR STUDIES AND FINDINGS}


Table 1. Characteristics of research informants Respondent Characteristics

\begin{tabular}{|c|r|l|r|r|}
\hline & Attribute & Category & Sum & \multicolumn{1}{c|}{$\%$} \\
\hline \multirow{2}{*}{1} & \multirow{2}{*}{ Gender } & Man & 85 & $42.5 \%$ \\
\cline { 3 - 5 } & & Women & 115 & $57.5 \%$ \\
\cline { 3 - 5 } & & Total & 200 & $100.0 \%$ \\
\hline \multirow{2}{*}{2} & \multirow{2}{*}{ Age } & $<=25$ y.o. & 181 & $90.5 \%$ \\
\cline { 3 - 5 } & & $>25$ y.o. & 200 & $9.5 \%$ \\
\cline { 3 - 5 } & & Total & & $100.0 \%$ \\
\hline
\end{tabular}

rom Table 4.2 shows that the respondents characteristics based on gender, it can be seen that in this study most of the respondents whom the author studied were women with a total of $57.5 \%$ (115 people) of 200 respondents, and for male respondents as much as $42.5 \%$ ( 85 people). Characteristics of respondents based on the age of the respondents found that most of the respondents who the author studied were aged less than 25 years, namely $90.5 \%$ (181 people) of 200 respondents, and for respondents who were more than 25 years old was $9.5 \%$ (19 people).

Table 2. HIS Implementation Variables Assessment

\begin{tabular}{|c|l|c|c|c|}
\hline No & \multicolumn{1}{|c|}{ Statement } & Mean & Standard deviation & Category \\
\hline 1 & HIS apps is easy to learn & 3,66 & 0,53 & Good \\
\hline 2 & HIS apps is easy to understand & 3,29 & 0,55 & Fairly good \\
\hline 3 & HIS apps can be quickly accessed & 3,28 & 0,59 & Fairly good \\
\hline 4 & HIS apps is fast in processing transactions & 3,22 & 0,50 & Fairly good \\
\hline 5 & & 3,21 & 0,50 & Fairly good \\
\hline 6 & HIS apps's features are make it easy for users & 3,19 & 0,47 & Fairly good \\
\hline 7 & HIS apps is stabil dan no damage record before & 2,92 & 0,68 & Fairly good \\
\hline 8 & HIS's connections rarely lost & 2,89 & 0,76 & Fairly good \\
\hline
\end{tabular}

Based on the table, it can be explained that the average assessment of the HIS implementation variable at RSGM UMY is quite good, it is shown from the average value of 3.24. The variable of HIS application in RSGM UMY is measured through 8 (eight) statement items and it is known that the HIS application is easy to learn is considered good with an average value of 3.66. The assessment of that the HIS software is easy to understand is considered quite good with an average value of 3.29, the assessment of that the HIS software can be accessed quickly is considered quite good with an average value of 3.28, the assessment of the statement that HIS software is fast in processing transactions assessed quite good with an average value of 3.22, the assessment of the statement that feature given in the HIS software makes it very easy for users to be considered good enough with an average value of 3.21, an assessment of the statement that HIS software has the features and functions needed by the user with The average value is 3.19, the assessment of the statement that HIS software is stable and so far there has been no damage with an average value of 2.92 and the assessment of the statement that the HIS software is rarely broken is considered quite good with an average value of 2.89 .

Table 3. Descriptive length of time for patient transfer from the emergency room to the inpatient room

\begin{tabular}{|c|l|c|c|l|}
\hline No & \multicolumn{1}{|c|}{ Statement } & Mean & Standard deviation & Category \\
\hline 1 & HIS provider provides assistance to users & 3,22 & 0,54 & Fairly good \\
\hline 2 & HIS provider makes it easy for users to work & 3,16 & 0,54 & Fairly good \\
\hline 3 & HIS provider is very concerned about the interests of its users & 3,25 & 0,60 & Fairly good \\
\hline 4 & Availability of server system as the main database of inputted data & 3,27 & 0,57 & Fairly good \\
\hline & mean & 3,27 & 0,60 & Fairly good \\
\hline
\end{tabular}

Based on the explanation above, it can be explained that on the average of assessment in the quality of HIS of the RSGM UMY is quite good, it is shown from the average value of 3.27. The quality of HIS variable is measured through 4 (four) statement and it is known that the assessment of the statement that the HIS provider provides assistance to users is considered quite good by the respondent, this is indicated by an average value of 3.22, the HIS provider make it easy for users to work, which is considered good enough by respondents with an average value of 3.16, the statement that the HIS provider is very concerned about the interests of the users is considered good enough by the respondents with an average value of 3.25 and the statement of the availability of a server system as the main data database 
is considered quite good by respondents with an average value of 3.27 .

Table 5. The analysis result of patient waiting time in the emergency department on the level of patient satisfaction

\begin{tabular}{|c|l|c|c|c|}
\hline No & \multicolumn{1}{|c|}{ Statement } & Mean & Standard deviation & Category \\
\hline 1 & $\begin{array}{l}\text { The content of the information } \\
\text { generated by the HIS apps is what I } \\
\text { need }\end{array}$ & 3,22 & 0,45 & quite satisfied \\
\hline 2 & $\begin{array}{l}\text { HIS apps generates the right report } \\
\text { as I want them }\end{array}$ & 3,22 & 0,53 & quite satisfied \\
\hline 3 & $\begin{array}{l}\text { I am satisfied with the accuracy } \\
\text { level }\end{array}$ & 3,19 & 0,56 & quite satisfied \\
\hline 4 & HIS apps is accurate & 3,20 & 0,57 & quite satisfied \\
\hline 5 & $\begin{array}{l}\text { His apps is able to provide } \\
\text { information what I need }\end{array}$ & 3,18 & 0,53 & quite satisfied \\
\hline 6 & $\begin{array}{l}\text { HIS apps is able to produce } \\
\text { information that can be clearly } \\
\text { understood }\end{array}$ & 3,23 & 0,56 & quite satisfied \\
\hline 7 & Easy to use & 3,25 & 0,53 & quite satisfied \\
\hline 8 & Ready on time & 3,21 & 0,53 & quite satisfied \\
\hline
\end{tabular}

Based on the table above, it can be explained that on average the assessment of the user satisfaction variable of the management information system at RSGM UMY is quite satisfied, it is shown from the average value of 3.25. The satisfaction variable of users of the management information system of RSGM UMY is measured through 8 (eight) statement items and it is known that the assessment of the statement that the content of the information generated by the HIS application used is needed by the respondent as quite satisfied by the respondent with an average value of 3.22 The HIS application statement used to produce the exact report I need was considered quite satisfied by the respondent with an average value of 3.22. Respondents' statement of being satisfied with the level of accuracy used was considered quite satisfied by respondents with an average value of 3.19. The HIS application statement used is accurate and is considered quite satisfied by the respondents with an average value of 3.20. The statement that the HIS application used is able to provide information in accordance with what the respondent needs is considered quite satisfied by the respondent with an average value of 3.18. The statement that the HIS application used was able to produce information that could be clearly understood by the respondents, with an average value of 3.23. The easy statement to use the hospital management information system application was considered quite satisfied by the respondent with an average value of 3.25 and the statement that the respondent was able to obtain the information needed on time was considered quite satisfied by the respondent with an average value of 3.21 .

This section will explain the results of the research analysis, as in the initial section it is explained that the purpose of this study is to find out and evaluate the effect of the Hospital Information System on the quality of information and user satisfaction (Dental Profession Students) at RSGM UMY. An information system is an integrated human or machine system to present information in support of operations, management and decision-making functions in an organization. The application of information systems in organizations is one of the most important parts in developing the capabilities of the company's human resources. The presence of information systems has had a lot of influence on an organization, not only the organization, but this influence extends to business processes and organizational transactions. Therefore, all information systems that are implemented in the organization should be able to provide satisfaction for system users.

The result of the analysis shows that the implementation of the management information system of the RSGM UMY as a whole is considered quite good by the respondents. These results can be explained that most of the respondents who were co-ass students stated that HIS was quite easy to learn, understand, could be accessed quickly and processed transactions quickly. In addition, respondents also stated that the features used are quite easy for users and these features are needed by users, their use has been quite stable so far and there have never been any problems with both the network and the connection.[5] Constraints that usually occur, according to respondents, have occurred but the intensity is not too frequent, such as system errors or long loading data, which are problems that have been occurring but can be resolved properly.

The quality of management information system is given a fairly good assessment by respondents. The results can be explained that RSGM UMY SIM provider is fairly good in providing assistance to users, [6] fairly good to facilitate student work, concern to the interests of students and the availability of a server system as the main database of data that has been inputted.

On the user satisfaction variable also shows the same rating that is in the category is quite satisfied. User satisfaction in this study is the overall evaluation of the user experience in using the management information system and the potential impact of the information system includes the content of information generated by the HIS application that is needed by the user, his application produces the right report as needed by the user, the user is satisfied with accuracy level, HIS is able to provide information that is in accordance with the needs and able to produce information that can be understood clearly. [7] 
User satisfaction that falls into the category of quite satisfied can be explained that the satisfaction of RSGM UMY SIM is quite successful in the quality of information and the quality of information produced by the information system, which can affect the satisfaction of users of the information system. Both are assumed to affect the user satisfaction of the information system. The better the quality of the system and the quality of the information produced, the more user satisfaction of the information system will be increased. Information systems can be relied upon if they have good system quality and information quality and are able to provide satisfaction to the wearer. Failure of an information system may be due to the inability of a system to meet the user's expectations. Satisfaction is often used as a proxy for the success of an information system.

The results of this study are supported by [4] which mentions that user satisfaction has an impact on individuals and organizations. HIS users make it easier and faster to serve customers so as to provide decisions for users and have a positive impact on the organization. User satisfaction of the system is a subjective attitude of the user who appears after using the information system.[8] This subjective attitude is a user's love of using the system and will affect the performance of individuals and organizations.

\section{CONCLUSION}

Based on the results of the research and discussion of the results of the research, then this research can be concluded that with the application of management information system in RSGM UMY can facilitate the work of students, it can be seen from the average respondent's answer on the application of management information system RSGM UMY which is considered quite good by respondents which means it can be concluded that HIS is quite easy to learn, understand and enough in providing assistance to most students with the availability of server system as a database of existing data. The results of the research from the aspect of user satisfaction obtained that the user OF HIS RSGM UMY expressed quite satisfied, it can be seen from the results of the average respondent where the content of information generated by the HIS application is needed by the user, produce the right report with the level of accuracy of HIS, in addition HIS is able to provide information that is in accordance with the needs and able to produce information that can be understood clearly.

The results of the study showed that most of the respondents gave quite good ratings, which meant that the implementation of HIS at RSGM UMY had not been rated to be the best by most of the respondents, therefore the results of this study could be used as a guideline for evaluation of implementing HIS so that it could be even better in implementing HIS at RSGM UMY. For the next researcher, it is better if you add the other variables that are more varied and adapted to the existing conditions with the research object and can lead to better research with a wider range of objects in order to produce more better results, besides that, cross tabulation analysis can also be carried out on the individual factors of the respondent, such as gender, age and so on.

\section{REFERENCES}

[1] Endang. (2014). Evaluasi Kinerja (SIM KA) di Puskesmas Halmahera. Journal SIADIN.

[2] Wicaksono, H. N., Utami, S. dan Witcahyo, E. (2016) “Analisis Kesuksesan Sistem Informasi Manajemen Menggunakan Pendekatan Updated D \& M Is Success Model Di Rumah Sakit Umum Kaliwates Jember ( The Successed Analysis of Management Information System by Updated D \& M IS Success Model Approached at The Kaliwat,” Repository.Unej.Ac.Id. Tersedia pada: https://repository.unej.ac.id/handle/123456789/83609.

[3] Kriyantono, R. (2012) Teknik Praktis Riset Komunikasi Cetakan Ke-6. Jakarta: Kencana Prenada Media Group.

[4] Wahyuni, V. \& M. (2015) “Evaluasi Sistem Informasi Manajemen RUmah Sakit (HIS) Menggunakan Metode Unified Theory of Acceptance and Use of Technology (UTAUT), ’ Jurnal Rekayasa dan Manajemen Sistem Informasi, 1, No. 1.

[5] Lande R, Kepel B.J, Siagian K.V. 2015. “Gambaran Faktor resiko dan Komplikasi Pencabutan Gigi Di RSGM PSPDG-FK UNSRAT”. Dalam Jurnal e-GIGI, Vol. 3. No. 2.

[6] DeLone, W. H., \& McLean, E. . (2003) “The DeLone and McLean Model of Information Systems Success: A ten-year update,” Journal of Management Information System, 19 (4), hal. 90-30. Tersedia pada: http://doi.org/10.1080/07421222.2003.11045748.

[7] DeLone, W.H. \& McLean, E. . (1992) “Information Systems Success: The Quest for The Dependent.” Tersedia pada: http://www.jstor.ord/stable/23010781.

[8] Balaraman, P. (2013) “Hosptal Management \& Hospital Information Systems - Changing Trends," International Journal of Information Engineering and Electronic Business, 5, hal. 50-58. Tersedia pada: https://doi.org/10.5815/ijieeb.2013.01.06.

\section{AUTHORS}

First Author - Puji Lestari, Universitas Muhammadiyah Yogyakarta and email: floristaedellweiss@gmail.com

Second Author - Titih Huriyah, Master of Nursing, University of Muhammadiyah Yogyakarta, Yogyakarta, Indonesia and email titih.huriah@umy.ac.id

Third Author - Puji Lestari, Master of Nursing, University of Muhammadiyah Yogyakarta, Yogyakarta, Indonesia and email titih.huriah@umy.ac.id

Correspondence Author - Puji Lestari, email floristaedellweiss@ gmail.com, contact number. Mobile No. +62 821-3792-6600 